$$
\text { F) }
$$


TAB. LXXVII.

\section{PARRA SINENSIS.}

THrs species may be distinguished not less by the grace and beauty of its form than by its adaptation to the localities which nature has allotted it. Formed for traversing the morass and the lotus-covered surface of the water, it supports itself upon the floating weeds and leaves by the extraordinary span of the toes, aided by the unusual lightness of its body. Like the Moor-hen, of whose habits and manners it largely partakes, it is doubtless capable of swimming, the long and pendent tail-feathers being elevated, when in that act, so as not to dip in the water. In powers of flight it appears deficient; the wings being short, and the quills terminated by a slender appendage proceeding from the tip of the shafts. This singular bird has been long known as a native of the low lands of India and China, but was not supposed, until its recent introduction from that quarter, to have been a native of the Himalaya, where it inhabits lakes and swamps among the hills.

The head, fore part of the neck, and chest, are white; a black line runs from the occiput down the sides of the neck, bordering a large orange-coloured patch, extending from the occiput down the back of the neck to the top of the back; the shoulders, wing-coverts, and a few of the outer secondaries, are white; the rest of the plumage a fine chocolate brown; beak and tarsi dull greenish olive. Its total length is 22 inches; the wing, 7 ; the tarsus, $2 \frac{1}{2}$; the naked part of the thigh, $1 \frac{1}{2}$; the expanse of foot from the end of the hind-toe to the end of the middle, 5 .

The bird is figured of the natural size. 


\section{$2 \mathrm{BHL}$ Biodiversity Heritage Library}

Gould, John. 1831. "Parra sinensis [Tab. LXXVII]." A century of birds from the Himalaya Mountains -. https://doi.org/10.5962/p.323607.

View This Item Online: https://www.biodiversitylibrary.org/item/132967

DOI: https://doi.org/10.5962/p.323607

Permalink: https://www.biodiversitylibrary.org/partpdf/323607

\section{Holding Institution}

Smithsonian Libraries

\section{Sponsored by}

Biodiversity Heritage Library

\section{Copyright \& Reuse}

Copyright Status: Public domain. The BHL considers that this work is no longer under copyright protection.

This document was created from content at the Biodiversity Heritage Library, the world's largest open access digital library for biodiversity literature and archives. Visit BHL at https://www.biodiversitylibrary.org. 